Int. J. Dev. Biol. 64: 141-149 (2020)

https://doi.org/10.1387/ijdb.190243sg

\title{
Cell signaling molecules in hydra: insights into evolutionarily ancient functions of signaling pathways
}

\author{
SURENDRA GHASKADBI* \\ Developmental Biology Group, MACS-Agharkar Research Institute, Pune, India
}

\begin{abstract}
Hydra, a Cnidarian believed to have been evolved about 60 million years ago, has been a favorite model for developmental biologists since Abraham Trembley introduced it in 1744. However, the modern renaissance in research on hydra was initiated by Alfred Gierer when he established a hydra laboratory at the Max Plank Institute in Göttingen in the late 1960s. Several signaling mechanisms that regulate development and pattern formation in vertebrates, including humans, have been found in hydra. These include Wnt, BMP, VEGF, FGF, Notch, and RTK signaling pathways. We have been using hydra to understand the evolution of cell signaling for the past several years. In this article, I will summarize the work on cell signaling pathways in hydra with emphasis on our own work. We have identified and characterized, for the first time, the hydra homologs of the BMP inhibitors Noggin and Gremlin, the vascular endothelial growth factor (VEGF), fibroblast growth factor (FGF) and several receptor tyrosine kinases (RTKs). Our work, along with that of others, clearly demonstrates that these pathways arose early in evolution to carry out functions that were often quite different from their functions in more complex animals. Apart from providing insights into morphogenesis and pattern formation in adult, budding and regenerating hydra, these findings bring out the utility of hydra as a model system to study evolutionarily ancient, in contrast to recently acquired, functions of various biological molecules.
\end{abstract}

KEY WORDS: cell signaling pathway, evolution, Hydra, pattern formation

\section{Introduction}

\section{Cell-cell signaling}

Evolution and survival of multicellular organisms depend on the close coordination between their constituent cells, and any coordinative activity of cells requires effective communication amongst themselves. Cells communicate with their near and distant neighbors or with cells located far away from them through various means. While cell-cell communication remains crucial throughout the life of an organism, it is particularly important, and spectacular, during development and pattern formation. During early embryonic development, the chemical communication between cells is predominantly of autocrine or paracrine nature; endocrine signaling mechanisms begin to operate much later. Construction of a metazoan body plan involves a large number of cellular interactions, such as, cell adhesion, cell migration, cell differentiation and cell death, over a fairly long period of time. In spite of this, a relatively small number of signaling pathways, namely, TGF-b, Wnt, Hedgehog, Notch, JAK/STAT, receptor tyrosine kinase (RTK), and nuclear hormone pathways, are sufficient for this purpose (Gerhart 1999; Reinhardt et al., 2004; De Robertis 2008; Babonis and Martindale 2017). These pathways operate in almost all the multicellular animals studied till date.

\section{Why hydra?}

Hydra is a basal metazoan that belongs to phylum Cnidaria, to which corals and jelly fish also belong. It is a fresh water diploblast with a simple but organized body plan (Bosch 2008). The body is cylindrical with an oral-aboral axis and radial symmetry. The oral end consists of a mouth-like opening called hypostome surrounded by $6-8$ tentacles (the number can vary within and across species) that help the animal sense and capture its prey. The aboral end has a 'foot' that helps the animal to attach to the substratum. Some species exhibit a stalk-like structure called peduncle just above the foot. The remaining part is called body column (Bode 2003). Hydra is made up of about 20-25 different cell types. It consists of three distinct stem cell lineages; the ectodermal epithelial stem cells, the endodermal epithelial stem cells and the interstitial or I

\footnotetext{
Abbreviations used in this paper: BMP, bone morphogenetic protein; FGF, fibroblast growth factor; RTF, receptor tyrosine kinase; VEGF, vascular endothelial growth factor.
}

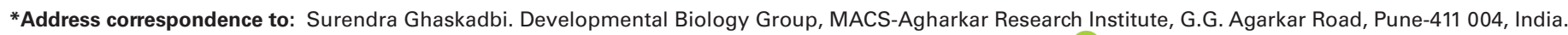
Phone: +91 20 25325063. Fax: +91 20 25651542. Email: smghaskadbi@aripune.org ; ghaskadbi@gmail.com - iD https://orcid.org/0000-0002-7367-2049
} 
cells. The first two give rise to ectodermal and endodermal epithelial cells while the third, the I cells, are truly multipotent since they can give rise to neurons, nematocytes, gland and mucous cells as well as sperm and ova, when required (Bode 1996, 2009). The I cells and their precursors reside in the ectoderm of the upper two third of the body column. The ectodermal and endodermal stem cells self-renew in about 3-4 days while the I cells recycle much faster, in about 1.5 days. Hydra exhibits peculiar cell dynamics in that the body cells are continuously replaced by new cells which are the differentiated progeny of the stem cells. Consequently, cellular processes such as cell proliferation, cell adhesion, cell migration, cell differentiation and cell death are always active in adult hydra polyps; it is therefore often referred to as everlasting embryo (Martinez and Bridge 2012). Hydra thus provides the unique opportunity to study several different embryonic phenomena in an adult organism. Further, hydra does not exhibit organismal senescence and is therefore considered to be potentially immortal (Martinez 1998).

Hydra is believed to have diverged from anthozoans about 60 million years ago (Martinez et al., 2010). In spite of its evolutionarily ancient origin, several genes and proteins in hydra exhibit close homology with their counterparts in vertebrates, including humans (Hobmayer et al., 2000; Galliot and Schmid 2002; Chandramore et al., 2010; Barve et al., 2013a, b). For example, hydra noggin mRNA, on injection in early Xenopus embryo, results in duplication of the dorsoventral axis (Chandramore et al., 2010); this clearly demonstrates that the noggin gene and its protein product are not only structurally but also functionally conserved in vertebrates (for details see section 3.3). Based on many such findings, it appears that the so-called genetic toolkit required to build multicellular organisms with extraordinary complexity already existed over 60 million years ago. This makes hydra a very powerful model system in evolutionary developmental (evo-devo) biology.

\section{Our hydra journey}

Our own interest in using hydra to answer some of the questions in developmental biology began with the discovery that the Wnt pathway is present and active in hydra (Hobmayer et al., 2000). In this study, it was elegantly shown that hydra possesses the Wnt pathway with several of the Wnt pathway players exhibiting close structural and functional homology with their vertebrate counterparts. The study revealed that hydra Wnt may be important during head formation. Until that time, it was generally believed that many signaling pathway may have evolved much later in evolution (in more complex metazoans) but the hydra Wnt paper offered a fresh line of thought. Until this time, our laboratory used chick and frog embryos to understand aspects of mesoderm and neural induction. However, for multiple reasons, probably unique to Indian conditions, the non-availability of good quality frog and chick embryos was becoming a serious impediment in our work. The three things, discovery of Wnt pathway in hydra, our previous experience of using hydra (Ghaskadbi and Mulherkar 1984) and the non-availability of good vertebrate embryos for experimentation, prompted us to turn to hydra. One of the interests in the lab at that time was how neural tissue is induced, and we reasoned that hydra, which is one of the first organisms to possess an organized nervous system, may be a useful model system to address this issue. We brought our first hydra polyp from botanical garden of Department of Botany, Savitribai Phule Pune University and started a culture in the year 2000, the progeny of that polyp are still maintained in
TABLE 1

\section{SIGNALING PATHWAYS IN HYDRA}

\begin{tabular}{|c|c|c|}
\hline Signaling pathway & Proposed function & References \\
\hline \multicolumn{3}{|c|}{ Canonical Wnt/ $\beta$ catenin signaling } \\
\hline$\beta$ catenin & $\begin{array}{l}\text { Axis formation } \\
\text { Formation of head organizer } \\
\text { - }\end{array}$ & $\begin{array}{l}\text { Hobmayer et al., } 2000 \\
\text { Broun et al., 2005 } \\
\text { Hobmayer et al., } 1996\end{array}$ \\
\hline Dickkopf & Antagonism of Wnt pathway (?) & Augustin et al., 2006 \\
\hline $\begin{array}{l}\text { Noncanonical and ca- } \\
\text { nonical Wnt signaling }\end{array}$ & Early bud evagination & Philipp et al., 2009 \\
\hline \multicolumn{3}{|l|}{ FGF signaling } \\
\hline Kringelchen (HvFGFR) & Bud detachment & Sudhop et al., 2004 \\
\hline FGF & $\begin{array}{l}\text { Interstitial cell maintenance (?) } \\
\text { Morphogenesis, cell differentiation (?) }\end{array}$ & $\begin{array}{l}\text { Krishnapati \& Ghaskadbi } 2013 \\
\text { Lange et al., } 2014\end{array}$ \\
\hline \multicolumn{3}{|l|}{ BMP pathway } \\
\hline BMP5-8b & $\begin{array}{l}\text { Tentacle formation, patterning of aboral } \\
\text { end of body axis }\end{array}$ & Reinhardt et al., 2004 \\
\hline Chordin & Organizer formation & Rentzsch et al., 2007 \\
\hline Noggin & Organizer formation (?) & Chandramore et al., 2010 \\
\hline Gremlin & $?$ & Krishnapati et al., pending \\
\hline \multicolumn{3}{|l|}{ VEGF pathway } \\
\hline VEGF & $\begin{array}{l}\text { Stem cell maintenance, tube formation } \\
\text { and/or branching (?) }\end{array}$ & $\begin{array}{l}\text { Böttger et al., } 2006 \\
\text { Krishnapati \& Ghaskadbi } 2013\end{array}$ \\
\hline \multicolumn{3}{|c|}{ Receptor tyrosine kinases (RTKs) } \\
\hline Lemon & Budding, gametogenesis (?) & Miller \& Steele 2000 \\
\hline $\begin{array}{l}\text { RTKs (genome-wide } \\
\text { Screen) }\end{array}$ & - & Reddy et al., 2011 \\
\hline Notch signaling & $\begin{array}{l}\text { Interstitial cell differentiation (?) } \\
\text { Boundary formation during budding } \\
\text { Head regeneration, tentacle patterning }\end{array}$ & $\begin{array}{l}\text { Käsbauer et al., } 2007 \\
\text { Münder et al., } 2010 \\
\text { Münder et al., } 2013\end{array}$ \\
\hline Nodal signaling & Determination of biradial asymmetry & Watanabe et al., 2014 \\
\hline Insulin signaling & Growth and patterning & Steele et al., 1996 \\
\hline $\begin{array}{l}\text { Insulin signaling (togeth- } \\
\text { er with temperature) }\end{array}$ & $\begin{array}{l}\text { Body size control (through Wnt and } \\
\text { TGF- } \beta \text { signaling pathways) }\end{array}$ & Benedict et al., 2019 \\
\hline
\end{tabular}

the laboratory, along with several other strains. As it turned out, instead of finding out how neural induction takes place in hydra, our work led to discovery of some molecules from hydra that are homologous to players that are part of cell-cell signaling repertoire of vertebrates. In this article, I will first briefly mention the various signaling pathways discovered in hydra so far and then review our studies on Noggin and Gremlin, inhibitors of bone morphogenetic protein (BMP) signaling pathway, the vascular endothelial growth factor (VEGF), RTKs and fibroblast growth factor (FGF) from hydra.

\section{Signaling pathways discovered so far in hydra}

The various signaling pathways discovered in hydra are listed in Table 1. We have identified noggin, VEGF, several RTKs and FGF from hydra. This work will be reviewed in the following sections. Characterization of gremlin from hydra that we recently identified is still going on at structural and functional levels; these results will not be covered here. Also, as in any other multicellular organism, signaling pathways do not function in isolation in hydra. The interactions between different signaling pathways will not be covered in this article. Further, though a mention of all the signaling pathway molecules in hydra reported till date will be made at some point or the other, only work from my own laboratory will be discussed in detail. 


\section{The bone morphogenetic protein (BMP) pathway}

\section{Hydra BMP}

BMP signaling pathway happens to be a key regulator of several developmental events. BMPs belong to the TGFb family of growth factors. They participate in the patterning of the mesoderm in vertebrate embryo. Hydra, however, is diploblastic, lacking mesoderm. It was therefore interesting to find out if hydra possesses BMP molecules and for what purpose. An orthologue of BMP5-8 was found in hydra (Reinhardt et al., 2004). Hydra smad (Hysmad), a molecule important in BMP signaling had already been reported from hydra (Hobmayer et al., 2001). Hysmad5-8 was found to be expressed at the base of tentacles in the adult polyp and at the points of origin of tentacles during bud formation and regeneration of head. It was concluded that Hysmad5-8 participates in the initiation and maintenance of tentacles (Reinhardt et al., 2004).

\section{Neural induction and dorsalization in Xenopus embryo}

One of the most critical features of regulation of the BMP signaling pathway in vertebrates is the involvement of a number of secreted BMP antagonists, such as, chordin, noggin, follistatin and gremlin, which bind to BMP ligands, inhibiting them from binding to their own receptors; this leads to inhibition of BMP signaling. Selective inhibition of BMP signaling is crucial for several biological processes during embryonic development, morphogenesis, organogenesis and tissue maintenance. One of the most crucial developmental events that results from BMP inhibition in the early amphibian embryo is neural induction. The respecification of part of the ectoderm to become neural ectoderm is brought about by the influence of Spemann's Organizer on the overlying ectoderm (Nieuwkoop 1952, 1985). By using an elegant experimental approach it was demonstrated that the influences from the Organizer are of an inhibitory nature (Hawley et al., 1995). These workers created and used dominant negative versions of XenopusBMP4 and BMP7 and after employing a multitude of controls, demonstrated that neural induction results due to inhibition of BMP signaling in a subset of ectodermal cells. In other words, ectodermal cells with persisting BMP signaling cannot take the neural pathway. An intense search for a 'neural inducer' was going on for decades, since, arguably, induction of the nervous system is one of the most crucial events in early development of animals. Findings of Hawley et al. (1995) narrowed down the search to molecules of the Spemann Organizer. Three neural inducers were identified in the early 1990s, all of which indeed turned out to be inhibitors of BMP. The first in the list was noggin (Smith and Harland 1992; Lamb et al., 1993) followed by chordin (Sasai et al., 1994, 1995) and follistatin (Hemmati-Brivanlou et al., 1994). Out of these, the first two, noggin and chordin also act as dorsalizing factors. Interestingly, it has been shown that there exists some redundancy of function between noggin, chordin and follistatin (Khokha et al., 2005; Dal-Pra et al., 2006). The first indication that BMP inhibitors may be present in hydra came from our own studies in 2001 (Chatterjee et al., 2001; Meinhardt 2004).

\section{Hydra noggin}

\section{Detection of noggin transcripts in hydra}

We began our work by looking for signaling molecules in hydra as one of our aims was to better understand the phenomenon of neural induction. Cnidarians were the first organisms to have evolved an organized nervous system. We reasoned that hydra, being a Cnidarian, might provide clues to how nervous system is formed. We started off by looking for presence of noggin in hydra. As discussed earlier, noggin is one of the neural inducers in vertebrate embryos. We looked for noggin transcripts in hydra by using heterologous probes from Xenopus. To our delight, we could detect expression of noggin in hydra by whole mount in situ hybridization (Chatterjee et al., 2001). Further, the expression pattern turned out to be very specific; noggin transcripts were localized to the hypostome, to the base of tentacles and to the basal region in the adult polyp (Fig. 1A). During budding, the preferred mode of reproduction in hydra, the transcripts were detected in the center of the bud in very early stages which subsequently became localized to the points of emergence of tentacles (Fig. 1B). Another gene studied along with noggin, goosecoid, exhibited a completely different pattern of expression (Chatterjee et al., 2001). We surmised that noggin may be involved in the differentiation of neurons as these reside at sites (Müller 1996) where we detected noggin transcripts. This work suggested that active transcription of genes important in morphogenesis and pattern formation in a fully developed hydra probably confers on it the remarkable ability to regenerate and be immortal. In spite of the fact that we had used heterologous probes, about which we were a bit uncomfortable then, the observations turned out to be absolutely spot on in our subsequent studies (see

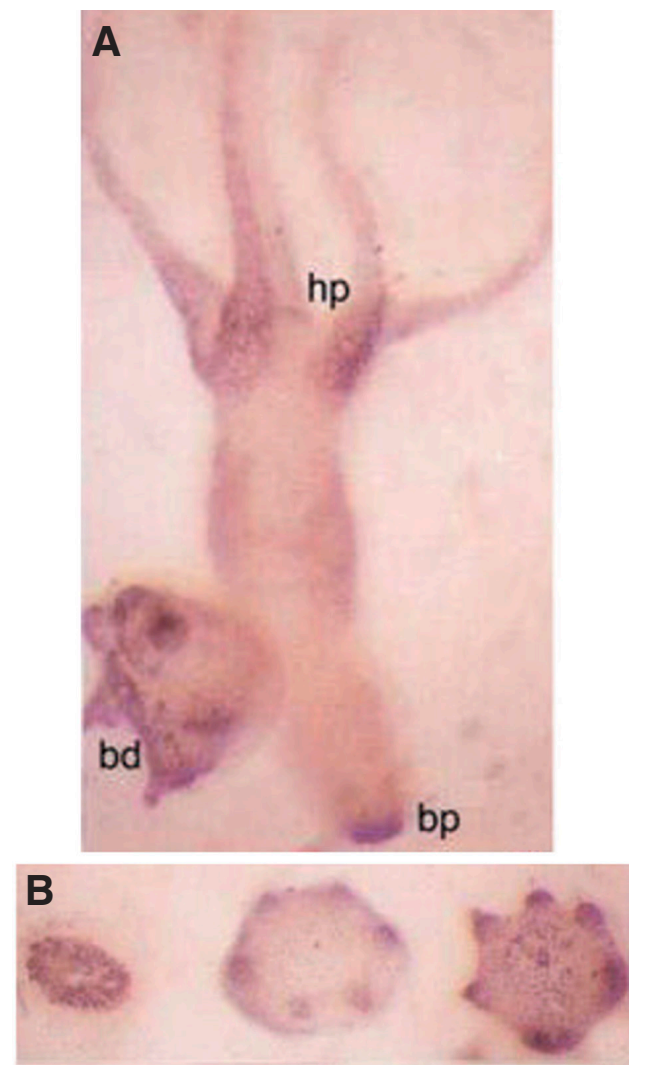

Fig.1. Noggin-like transcripts in hydra. (A) Noggin-like transcripts in the hypostomal region (hp) and basal disc (bp) in an adult hydra. (B) Noggin-like transcripts during budding. The bud on the left is youngest in developmental age. Reproduced from Chatterjee and Ghaskadbi (2001) with permission from Journal of Biosciences. 

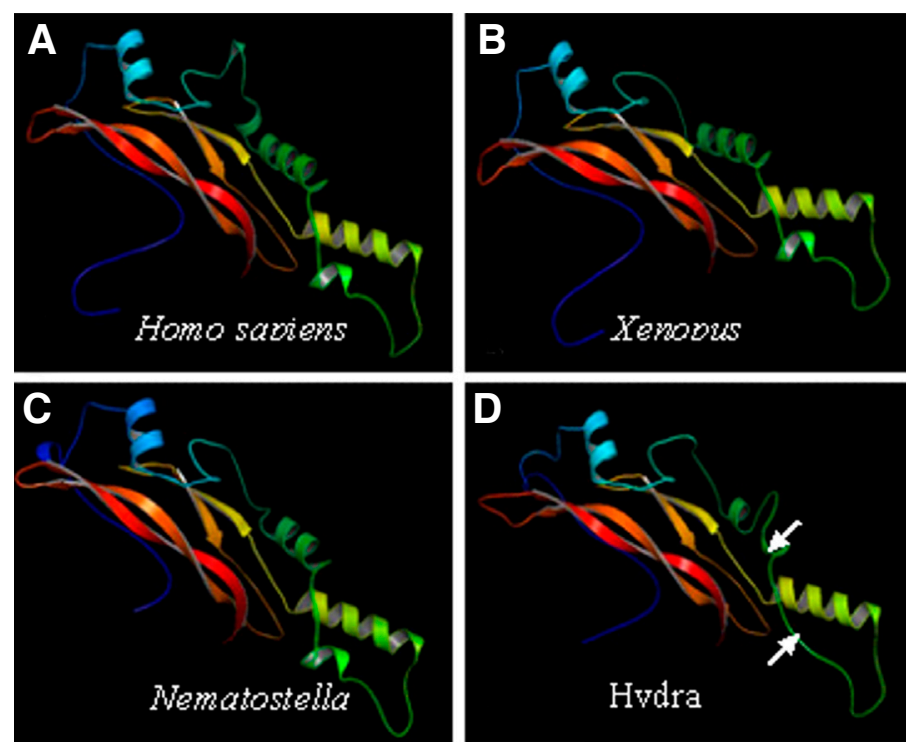

Fig. 2. Comparative analysis of hydra Noggin protein structure. Protein structures of Homo sapiens (A), Xenopus laevis (B), Nematostella (C) and hydra (D). Noggins were deduced using Swiss Model program based on homology modeling. In hydra Noggin, two helices are absent (the regions are indicated by white arrows) as compared to other Noggin proteins. Reproduced with permission from Chandramore et al. (2010) from John Wiley and Sons.

later). This was, to our knowledge, the first report of existence of a BMP inhibitor in hydra. The work was cited by Hans Meinhardt (Meinhardt 2004), which was a great incentive for us to carry on.

Expression of noggin in the hypostome and basal disk was interesting since these regions function as organizers and are capable of inducing an axis on transplantation to a host hydra (Browne 1909; Kadu et al., 2012; Gilbert and Barresi 2018). Our results thus indicated that noggin is expressed in the hydra organizer, just like in the amphibian organizer.

\section{Characterization of hydra noggin}

It took us quite a while to establish a reasonably good hydra laboratory at Agharkar Research Institute, Pune, India. There was no other group in India working on hydra at that time (even today, unfortunately, there are just a few). By this time, information on hydra ESTs became easily available through the sequencing of the hydra genome took a while (Chapman et al., 2010). By using a combination of techniques in bioinformatics, molecular biology and embryology, we could identify and to some extent characterize hydra noggin (Chandramore et al., 2010). It showed significant homology with its orthologues at the amino acid level. Several amino acid residues conserved in vertebrates, including characteristic cysteine residues of the noggin family, and the nine cysteine residues that confer conformational rigidity to the long finger of human noggin (Groppe et al., 2002), are present in hydra. Homology modeling revealed significant similarities in the three-dimensional structure of hydra noggin with those of humans, Xenopus and Nematostella, a starlet sea anemone (Fig. 2). This was exciting discovery indeed!

Mere structural conservation of hydra noggin in vertebrates did not necessarily mean, however, that it is functionally conserved in more complex organisms. A favorite assay to address this question is to express the hydra molecule in question in Xenopus embryos and see if a phenotype is induced (for example, see Hobmayer et al., 2000). We injected mRNA for hydra noggin in early Xenopus embryos and observed axis duplication in $100 \%$ of embryos. This confirmed the functional conservation of hydra noggin in vertebrates (Chandramore et al., 2010). As mentioned earlier, noggin acts as a dorsalizing factor in Xenopus embryos. We designed experiments to find out if hydra noggin exerts a dorsalizing effect in Xenopus embryos. It is known that exposure of very early Xenopus embryos to ultraviolet (UV) radiation causes ventralization (formation of ventral rather than dorsal structures: De Robertis et al., 2000; Fang et al., 2000) and such embryos can be rescued by over-expression of Xenopus noggin (Smith et al., 1993). We performed this experiment using hydra noggin in Xenopus embryos with appropriate controls and found that hydra noggin can rescue Xenopus embryos from UV radiation-induced dorsalization (Fig. 3). This was extremely interesting since hydra does not possess a dorsal-ventral axis, or for that matter an anterior posterior axis (Meinhardt 2002). That hydra noggin brings about its effects in Xenopus embryos by inhibiting the BMP pathway was confirmed by using the animal cap assay (Chandramore et al., 2010). The results clearly mean that whatever the function(s) of noggin in hydra, its function as a dorsalizing factor is a recent evolutionary acquisition.

\section{Hydra chordin}

Along with noggin, chordin plays an important role in many developmental processes (for review, see Bier and De Robertis 2015). An important paper (Rentzsch et al., 2007) reported chordin-like gene (HyChdl) from hydra which exhibits close structural similarity with other chordins and is capable of inhibiting BMP signaling in zebrafish embryos. HyChdl was upregulated during several patterning events, such as budding, regeneration and reaggregation. The overall findings of this study showed that HyChdl plays an important role in the formation of the head organizer in hydra. This study once again showed the evolutionarily ancient role of BMP antagonists.

\section{Hydra gremlin}

We have recently identified and partially characterized gremlin from hydra, which seems to be structurally conserved up to humans (Krishnapati L.S. et al., unpublished). The expression pattern of gremlin in hydra and elucidation of its function is in progress.

\section{Vascular endothelial growth factor (VEGF)}

As a part of our continued effort to identify signaling pathways in hydra, we decided to look for the existence of vascular endothelial growth factor (VEGF) in hydra. Though VEGF in hydra was first detected in a genetic screen for signal peptides in hydra (Böttger et al., 2006), characterization of hydra VEGF had remained to be done. VEGF is a member of the platelet derived growth factor (PDGF) family and plays an important signaling role in formation of vascular system in the developing embryo (vasculogenesis) and formation of new blood vessels (angiogenesis). Though initially isolated as an endothelial-specific growth factor, several cells of non-endothelial origin, such as, Schwann cells, astrocytes, nerve cells, and neural stem cells secrete VEGF. VEGF has been implicated in neuronal growth in vitro and in vivo (Jin et al., 2002; Ruiz de Almodovar et al., 2009). What further prompted us to look for 
VEGF in hydra was that its Cnidarian relative jelly fish Podocoryne carnea possesses homologues of VEGF and vascular endothelial growth factor receptor (VEGFR). Hydra lacks blood and blood vessels, which are of mesodermal origin. Moreover, in an earlier study (Reddy et al., 2011), we had detected homologues of VEGFR in hydra (for details see section 6 ). We therefore decided to find out if VEGF exists in hydra and if it does, what could be its role.

We detected putative gene model for VEGF in Hydra magnipapillata genome browser (Krishnapati and Ghaskadbi 2013). In silico analysis revealed that it contains the characteristic PDGF domain. We cloned VEGF from Hydra vulgaris Ind Pune and studied its expression pattern by whole mount in situ hybridization and semiquantitative RT-PCR. VEGF was found to be expressed in the body column and the tentacles with very high expression in the lower one third of the body column. Transverse sections of these polyps showed that VEGF was expressed more in the endoderm than the ectoderm; this was confirmed using semi-quantitative RT-PCR in separated ectodermal and endodermal tissue (Fig 4). To further substantiate this observation, we used a mutant hydra, sf-1 hydra (Sugiyama and Fujisawa 1978), which loses its nematocytes when transferred to the higher temperature of $28^{\circ} \mathrm{C}$ from the normal temperature of $18^{\circ} \mathrm{C}$ at which it is maintained. Hydra maintained at $28^{\circ} \mathrm{C}$ showed higher levels of VEGF as they did not contain nematocytes, which reside exclusively in the ectoderm (fig. 5).

In order to find out the function of VEGF in hydra, we treated non-budding and budding polyps as well as head and foot pieces
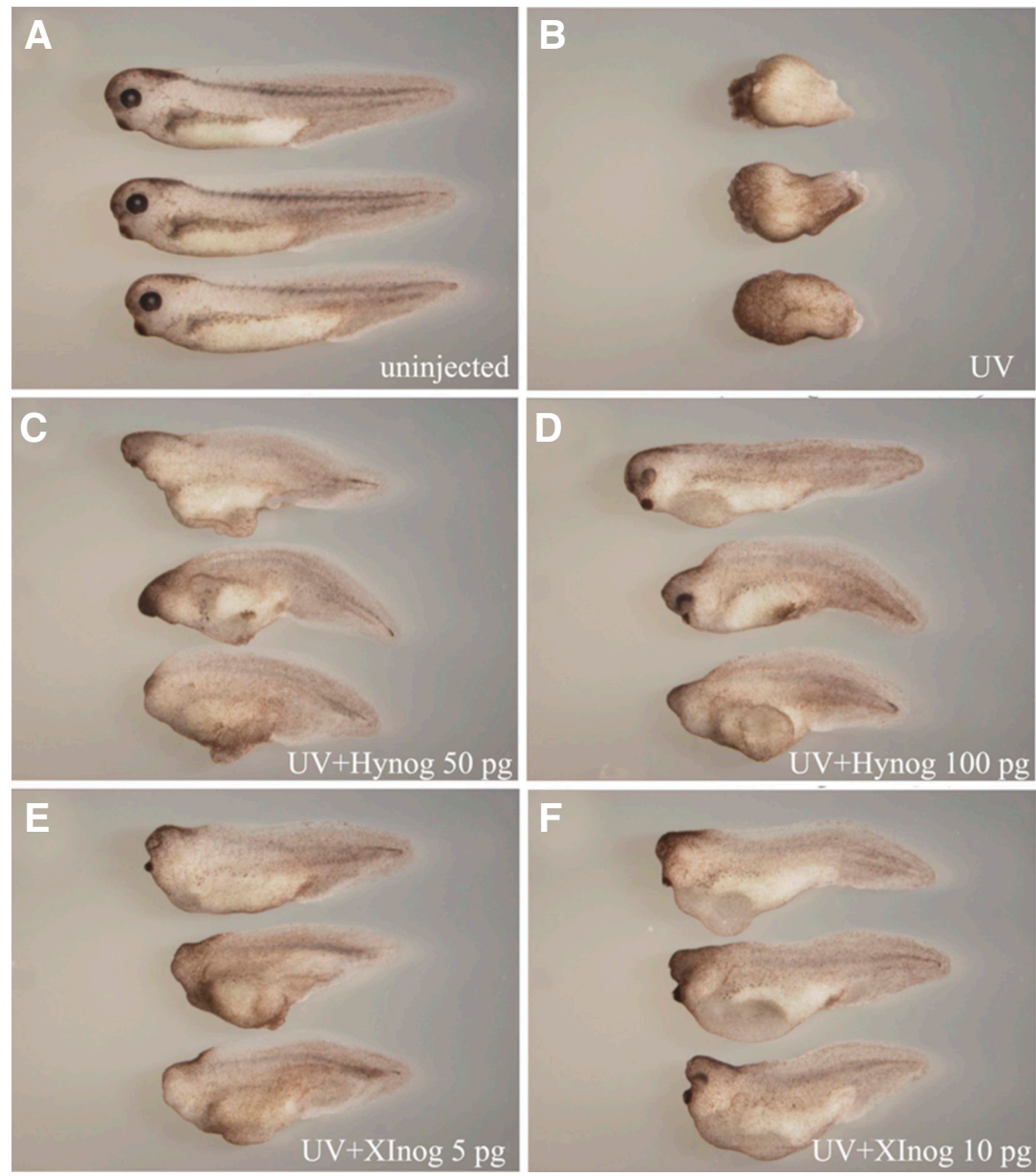

of bisected hydra with SU5416 (Semaxanib) which inhibits VEGF signaling by specifically inhibiting VEGF receptor tyrosine kinase 2 (KDR/Flk-1). While non-budding polyps did not respond to the treatment, except for occasional blebbing at tentacles, the processes of budding and head regeneration were affected adversely. Elongation of buds was irreversibly inhibited while formation of tentacles was inhibited in the foot piece which was in the process of regenerating a head. Interestingly, regeneration of foot in the head piece was not affected by inhibition of VEGF signaling. The results clearly indicated that VEGF signaling plays an important role on tube formation/ branching of structures in hydra similar to its role during vasculogenesis and angiogenesis. The role of VEGF in branching and tube formation, thus, seems to be evolutionarily quite ancient.

\section{Fibroblast growth factor (FGF)}

FGF signaling is important in a large number of biological processes throughout the life of an organism. It is also one of the most crucial signaling pathways during morphogenesis and pattern formation. Its role in mesoderm and neural induction and development has been well documented in frog and chick embryo (for reviews, see Smith 1989; Ghaskadbi 1996). In view of hydra possessing several of the most important signaling pathways, we decided to search for FGF signaling in hydra. In the early 2000s, Kringelchen, a receptor tyrosine kinase similar to FGFR tyrosine kinase, was implicated in detachment of bud in hydra (Sudhop et al., 2004). However, whether hydra possesses FGF remained an open question. Another Cnidarian, the starlet sea anemone Nematostella vectensis, has both FGF and FGFR homologues that play a role in gastrulation and neural induction (Matus et al., 2007). We identified a putative gene for FGF from Hydra magnipapillatagenome browser, cloned a partial CDS of FGF from Hydra vulgaris Ind-Pune and followed this up with its bioinformatics and expression pattern analyses (Krishnapati and Ghaskadbi 2013). FGF is expressed in the body column with higher expression in the budding region, and predominantly in the ectoderm, unlike VEGF which was more in the endoderm (Fig. 4). Removal of nematocytes in sf-1 hydra after a heat shock (by maintaining them at $28^{\circ} \mathrm{C}$ rather than at the normal $18^{\circ} \mathrm{C}$ temperature) reduced the expression of FGF (Fig. 5). We surmise that FGF is present in interstitial cells, the multipotent stem cell lineage in hydra and may be important in maintenance of their stemness. A subsequent study reported several FGFs from hydra (Lange et al., 2014). Based on extensive tissuespecific expression analysis by whole mount in situ

Fig. 3. Hydra noggin rescues Xenopus embryos from UV-induced ventralization. (A) Uninjected embryos. (B) UV-irradiated embryos. (C) 50 pg hydra Noggin mRNA injected into UV-irradiated embryos. (D) 100 pg hydra Noggin mRNA injected, as in (C). (E) 5 pg Xenopus Noggin mRNA injected as in (C). (F) 10 pg Xenopus Noggin mRNA injected as in (C). Reproduced with permission from Chandramore et al. (2010) from John Wiley and Sons. 


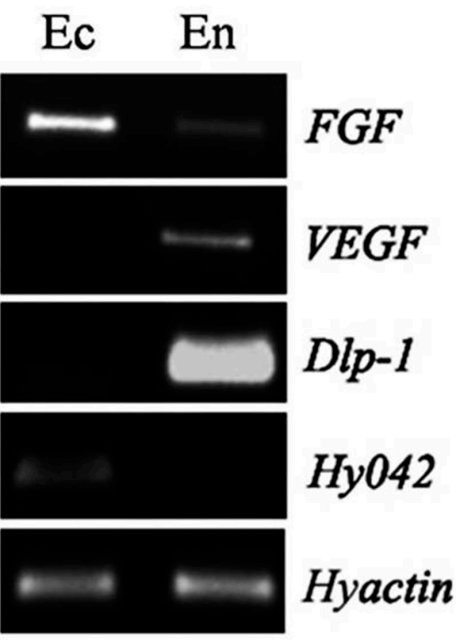

Fig. 4. Tissue specific expression of VEGF and $F G F$ in hydra. Endodermal expression of $V E G F$ and expression of $F G F$ in both tissue layers is observed by RT-PCR. Clean separation of ectoderm (EC) and endoderm (En) was confirmed by the expression of Hy042 and DIp1 in ectodermal and endodermal tissues respectively. Histogram represents the relative abundance of transcripts of $\mathrm{Hy} 042$, DIp1, VEGF and FGF in ectoderm and endoderm. ${ }^{*}$ shows statistical significance, $p<0.001$. Reproduced with permission of UPV/EHU Press from Krishnapati, L.-S. and Ghaskadbi, S. (2013). Identification and characterization of VEGF and FGF from hydra. Int. J. Dev. Biol. 57: 877-886 (doi: 10.1387/ijdb. 130077sg). hybridization of many FGFs and functional analysis of a few of them, a model for their possible function was proposed according to which FGFs are believed to be involved in cell migration and morphogenesis in hydra.

\section{Receptor tyrosine kinases (RTKs)}

RTK signaling is one of the seven major signaling pathways in animals (Gerhart 1999), which regulate proliferation, differentiation, migration, metabolism and survival of cells (van der Geer et al., 1994). Importance of RTKs in morphogenesis and pattern formation in Cnidarians was underlined by work on hydra (Sudhop et al., 2004) and Nematostella (Matus et al., 2007). Using bioinformatics approach, we found a total of 15 RTKs, 10 of which were identified for the first time (Table 2). These include homologues of receptor kinases involved in a wide variety of signaling pathways, such as, insulin receptor kinase (HTK7), ephrin receptors (HyEph1, HyEph2 and HyEph3), FGF receptor (Kringelchen), muscle specific kinase (MuSK), receptor tyrosine kinase-like orphan receptor (ROR), discoidin domain receptor (DDR) tyrosine kinase and Wnt inhibitory receptor tyrosine kinase (RyK). A mere glance at the variety of receptor kinases is sufficient to appreciate the complexity of signaling that already existed in hydra. A detailed bioinformatics and phylogenetic analyses of the data brought out some significant information about evolution of RTKs and its implications for the evolution of metazoans themselves. For example, a comparison with RTKs in sponges (phylum Porifera) showed that hydra (phylum Cnidaria) contain many more RTKs. It may be pointed out that unlike the poriferans, cnidarians have an organized body. One may infer that RTKs probably played a significant role in this transition during evolution. The findings showed that most of the subfamilies of RTKs evolved before the diploblast-triploblast split. It will be interesting to study how these very RTKs are employed and regulated to build more and more complex metazoan bodies. A study published soon after, reported four ephrin receptors and three ephrin class B ligands (Tischer et al., 2013). Importantly, the expression of the receptors and their ligands was found to be complementary by in situ hybridization. It was proposed that these signaling molecules play an important role in epithelial cell migration and tissue boundaries.

As mentioned earlier, this review focuses on work carried out in my laboratory. Detailed discussion on signaling pathway molecules in hydra reported by other laboratories (please see Table 1 ) is outside the scope of the present review article. This includes structural and/or functional characterization of players in canonical and noncanonical Wnt (Hobmayer et al., 1996; Hobmayer et al., 2000; Broun et al., 2005; Augustin et al., 2006; Philipp et al., 2009), BMP (Reinhardt et al., 2004; Rentzsch et al., 2007), FGF
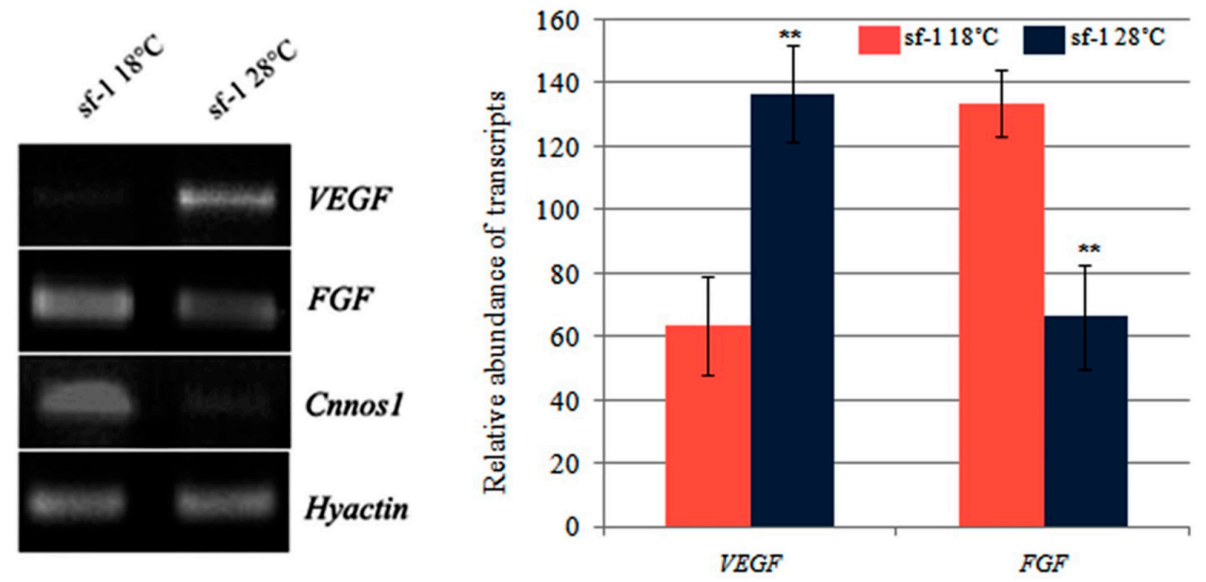

Fig. 5. Expression analysis of VEGF and FGF in sf-1 hydra. RT-PCR results show significant up-regulation of VEGFand down-regulation of FGF in sf-1 hydra. The loss of multipotent stem cells is evident from decreased expression of Cnnos1. Histogram represents relative abundance of transcripts of VEGF, FGF and Cnnos 1 in sf-1 hydra maintained at $18^{\circ} \mathrm{C}$ and $28^{\circ} \mathrm{C}$. ** shows corresponding statistical significance, $p<0.001$. Reproduced with permission of UPV/EHU Press from Krishnapati, L. S. and Ghaskadbi, S. (2013). Identification and characterization of VEGF and FGF from hydra. Int. J. Dev. Biol. 57: 877-886 (doi: 10.1387/ijdb.130077sg). 
TABLE 2

\section{PREDICTED AND KNOWN RTKs IN HYDRA}

\begin{tabular}{|c|c|c|c|c|c|c|}
\hline Peptide No & Contig location & Homologous gene & E-value & $\begin{array}{l}\text { Domain } \\
\text { organization }\end{array}$ & Reported RTK & $\begin{array}{l}\text { Proposed } \\
\text { names }\end{array}$ \\
\hline Hma1.132331 & $\begin{array}{l}\text { Contig38051:50217..12169 } \\
\text { (- strand) }\end{array}$ & $\begin{array}{l}\text { insulin-like growth factor } 1 \text { receptor } \\
\text { [Gallus gallus] }\end{array}$ & $1 e-137$ & L, Fu, L, FN3 [2], TM, TyK & HTK7 & HTK7 \\
\hline Hma1.111331 & $\begin{array}{l}\text { Contig38570:40247..13892 } \\
\text { (- strand) }\end{array}$ & $\begin{array}{l}\text { fibroblast growth factor receptor } 3 \text { isoform } 2 \text { precursor } \\
\text { [Homo sapiens] }\end{array}$ & $1 e-92$ & IG, TM [?], TyK & Kringelchen & HyFGR \\
\hline Hma1.109257 & $\begin{array}{l}\text { Contig38800:100449..95314 } \\
\text { (- strand) }\end{array}$ & $\begin{array}{l}\text { fibroblast growth factor receptor } 1 \\
\text { [Bos taurus] }\end{array}$ & $4 e-38$ & IG[3], TM, TyK & - & HylG1 \\
\hline $\begin{array}{l}\text { Hma1.117099 } \\
\text { Hma1.117098 }\end{array}$ & $\begin{array}{l}\text { Contig39071:63965..55113 } \\
\text { (- strand) }\end{array}$ & $\begin{array}{l}\text { Unc-89 CG33519-PC, isoform C [Drosophila melanoga- } \\
\text { ster] }\end{array}$ & $4 e-28$ & IG[2], TM [?], Tyk & - & HylG2 \\
\hline $\begin{array}{l}\text { Hma1.115640 } \\
\text { Hma1.115641 }\end{array}$ & $\begin{array}{l}\text { Contig38733:12578..38348 } \\
\text { (+ strand) }\end{array}$ & ret proto-oncogene [Gallus gallus] & $3 e-47$ & IG, TM, TyK & HTK32 & HTK32 \\
\hline- & - & FGFR [Branchiostoma belcheri] & $1 e-37$ & EGF[5], TM, TyK & HTK30 & НТКЗ \\
\hline $\begin{array}{l}\text { Hma0.51632 } \\
\text { Hma1.133499 }\end{array}$ & $\begin{array}{l}\text { Contig38716:99808..109204 } \\
\text { (+ strand) }\end{array}$ & $\begin{array}{l}\text { vascular endothelial growth factor receptor [Podocoryne } \\
\text { carnea] }\end{array}$ & $4 e-150$ & IG[5], TM, TyK & - & HylG3 \\
\hline $\begin{array}{l}\text { Hma1.124710 } \\
\text { Hma1.126334 }\end{array}$ & $\begin{array}{l}\text { Contig39302:30843..0 } \\
\text { (-strand ) } \\
\text { Contig36702:87346-69472 } \\
\text { (-strand) }\end{array}$ & $\begin{array}{l}\text { vascular endothelial growth factor receptor [Podocoryne } \\
\text { carnea] }\end{array}$ & $4 e-117$ & SP, IG[4], TM, TyK & HTK54 & HTK54 \\
\hline $\begin{array}{l}\text { Hma1.134245 } \\
\text { Hma1.126639 }\end{array}$ & $\begin{array}{l}\text { Contig39007:39509..102966 } \\
\text { (+ strand) }\end{array}$ & $\begin{array}{l}\text { vascular endothelial growth factor receptor [Podocoryne } \\
\text { carnea] }\end{array}$ & $2 e-131$ & SP, IG[4], TM, TyK & $\begin{array}{l}\text { HTK156 (only Tyk } \\
\text { domain) }\end{array}$ & HylG4 \\
\hline Hma1.122109 & $\begin{array}{l}\text { Contig34004:21687..46055 } \\
\text { (+ strand) }\end{array}$ & Embryo Brain Kinase [Mus musculus] & $1 e-90$ & FN3, TM, TyK, SAM & - & HyEph1 \\
\hline Hma1.108443 & $\begin{array}{l}\text { Contig36970:7835..63036 } \\
\text { (+ strand) }\end{array}$ & epha4a [Danio rerio] & $5 e-80$ & Ephrin_lbd, FN3, TM, TyK, SAM & - & HyEph2 \\
\hline Hma1.109586 & $\begin{array}{l}\text { Contig38965:146306..212650 } \\
\text { (+ strand) }\end{array}$ & EPH receptor A5 [Gallus gallus] & $5 e-131$ & Ephrin_Ibd, FN3, TM, TyK, SAM & - & HyEph3 \\
\hline $\begin{array}{l}\text { Hma1.100423 } \\
\text { Hma1.129666 }\end{array}$ & $\begin{array}{l}\text { Contig34224:25519...47282 } \\
\text { (+ strand) }\end{array}$ & $\begin{array}{l}\text { discoidin domain receptor family, member } 2 \text { [Rattus } \\
\text { norvegicus]. }\end{array}$ & $9 e-80$ & Discoidin, TM, TyK & $\begin{array}{l}\text { PTK66(only TK } \\
\text { domain) }\end{array}$ & HyDDR \\
\hline Hma1.132063 & $\begin{array}{l}\text { Contig37852:116464...98609 } \\
\text { (- strand) }\end{array}$ & $\begin{array}{l}\text { MuSk } \\
\text { muscle, skeletal, receptor tyrosine kinase, } \\
\text { isoform CRA_b [Mus musculus] }\end{array}$ & $5 e-64$ & SP, Fz, TM, TyK & - & HyMuSK \\
\hline Hma1.131548 & $\begin{array}{l}\text { Contig37394:49950.. } 44194 \\
\text { (- strand) }\end{array}$ & Ror1 [Mus musculus] & $3 e-44$ & IG, Fz, Kringle [2], TM [?], TyK & $\begin{array}{l}\text { HTK orphan } \\
\text { receptor }\end{array}$ & HyROR \\
\hline $\begin{array}{l}\text { hydra_sm. } 11813 \\
\text { hydra_sm.11814 }\end{array}$ & $\begin{array}{l}\text { Contig37331:71783..99524 } \\
\text { (+ strand) }\end{array}$ & receptor-like tyrosine kinase(Ryk) [Mus musculus] & $2 e-76$ & Wi, TM[?/], TyK & - & HyRyK \\
\hline Hma1.132874 & $\begin{array}{l}\text { Contig38400:128539..125171 } \\
\text { (- strand) }\end{array}$ & Ptk7 protein [Mus musculus] & $2 e-45$ & IG[3],TM, TyK & HTK90 & НyHTK90 \\
\hline
\end{tabular}

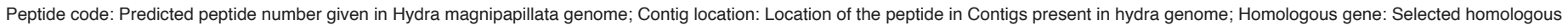

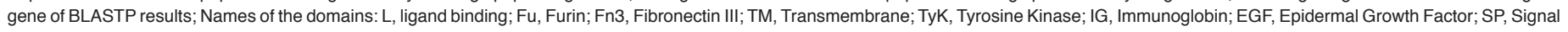

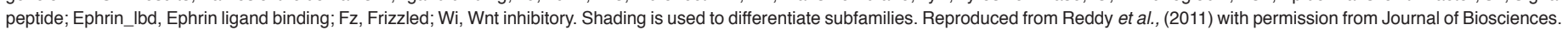

(Sudhop et al., 2004; Lange et al., 2014), and Notch and Nodal pathways (Käsbauer et al., 2007; Münder et al., 2010; Münder et al., 2013; Watanabe et al., 2014).

\section{Summary and conclusions}

Hydra is an evolutionarily ancient organism, believed to have evolved over 60 million years ago. In spite of its early origin, it displays a definite body plan, an organized nervous system and three distinct stem cell populations. Because of its spectacular regenerative ability and lack of organismal senescence, hydra has been an attractive model for biologists. Over the past couple of decades, studies on regeneration and pattern formation in hydra have received a huge impetus because of the identification of almost all the major cell signaling pathways in it (Babonis and Martindale 2017). The different signaling players from hydra usually show a close homology with those in more complex organisms including humans. Many signaling molecules from hydra produce phenotypes when expressed in vertebrate embryos, demonstrating their functional conservation from hydra to vertebrates. While hydra provides important clues on evolution of cell signaling in animals, the model system has some serious shortcomings. Due to its peculiar cellular dynamics, amongst other things, it is difficult to induce heritable mutations in hydra. Even the siRNA technology is yet to be perfected in this system. Further, for some reason, it has not been possible to establish cell lines from hydra. One hopes that at least some of these problems will be overcome in the near future, making hydra a more versatile model system in Evo-devo of not only cell signaling but also tissue regeneration and aging. Finally, deciphering functions of signaling molecules in hydra and comparing them with their functions in more complex organisms including humans will give us insights into their ancestral versus newly acquired functions, throwing light on evolution itself.

\section{Acknowledgements}

I thank Drs. Makoto Asashima (Tokyo University, Japan), Thomas Bosch (Kiel University, Germany) and Vidya Patwardhan (MACS-Agharkar Research Institute) for discussions and various help. I also thank my graduate students for agreeing to work with hydra that allowed me to establish a hydra laboratory. Work from my laboratory was funded by extramural grants from Science and Engineering Research council(SERB), Department of Science and Technology (DST: Government of India), Department of Biotechnology (DBT: Government of India) and Emeritus Scientist Scheme 
from Council for Scientific and Industrial Research (CSIR), New Delhi. MACS-Agharkar Research Institute, Pune, provided generous intramural support throughout. I would like to put on record that my wife Prof. Saroj Ghaskadbi (S.P. Pune University) not only provided valuable inputs in all my work in hydra biology but also nudged me to take up work on hydra in the first place.

\section{References}

AUGUSTIN R, FRANKE A, KHALTURIN K, SIEBERTBS, HEMMRICK G, BOSCH T $C$ (2006). Dickkopf related genes are components of the positional value gradient in hydra. Dev Biol 296: 62-70.

BABONIS L S, MARTINDALE M Q (2017) Phylogenetic evidence for the modular evolution of metazoan signaling pathways. Phil Trans R Soc B 372: 20150477.

BARVE A, GHASKADBI S, GHASKADBI S (2013a) Conservation of the nucleotide excision repair pathway: characterization of hydra xeroderma pigmentosum group F homolog. PLOS One 8: e61062.

BARVEA, GHASKADBI S, GHASKADBI S (2013b). Structural and sequence similarities of hydra xeroderma pigmentosum A protein to human homolog suggest early evolution and conservation. Biomed Res Int 2013: 854745.

BENEDICT M, MORTZFELD B M, TAUBENHEIM J, KLIMOVICH A V, FRAUNE S, ROSENSTIEL P, BOSCH T C G (2019). Temperature and insulin signaling regulate body size in Hydra by the Wnt and TGF-beta pathways. Nature Commun doi: 10.1038/ s41467-019-11136-6.

BIER E, DE ROBERTIS E M (2015). BMP gradients: A paradigm for morphogenmediated developmental patterning. Science 348: aaa5838.

BODE H (1996). The interstitial cell lineage of hydra: a stem cell system that arose early in evolution. J Cell Sci 109: 1155-1164.

BODE H (2003). Head regeneration in hydra. Dev Dyn 226: 225-236.

BODE H (2009). Axial patterning in hydra. Cold Spring Harb Perspect Biol doi: 10.1101/cshperspect.a000463.

BOSCH T C H (2008). Stem Cells in Immortal Hydra. In: Stem Cells: from Hydra to Man.(Ed. T C G Bosch). Springer Press, Netherlands, pp. 37-57.

BÖTTGER A, STRASSER D, ALEXANDROVA O, LEVIN A, FISCHER S, LASI M, RUDD S, DAVID CN (2006). Genetic screen for signal peptides in Hydra reveals novel secreted proteins and evidence for non-classical protein secretion. Eur $J$ Cell Biol 85: 1107-1117.

BROUN M, GEE L, REINHARDT B, BODE H R (2005). Formation of the head organizer in hydra involves the canonical Wnt pathway. Development 132: 2907-2916.

BROWNE E N (1909). The production of a few hydranths in hydra by the insertion of small grafts. J Exp Zool 8: 1-23.

CHANDRAMORE K, ITO T, TAKAHASHI S, ASASHIMA M, GHASKADBI S (2010) Cloning of noggin gene from hydra and analysis of its functional conservation using Xenopus laevis embryos. Evol Dev 12: 267-274.

CHAPMAN J A, KIRKNESS E F, SIMAKOV O, HAMPSON S E, MITRO T, et al., (2010) The dynamic genome of Hydra. Nature 464: 592-596.

CHATTERJEE S, LAHUDKAR S, GODBOLE N N, GHASKADBI S (2001). Hydra constitutively expresses transcripts involved in neural differentiation. J Biosci 26: 153-155.

DAL-PRAS. FÜRTHAUER M, VAN-CELST J, THISSE B, THISSE C (2006). Noggin1 and follistatin-like2 function redundantly to Chordin to antagonize BMP activity. Dev Biol 298: 514-526.

DE ROBERTIS E M (2008). Evo-Devo: Variations on ancestral themes. Cell 132: 185-195.

DE ROBERTIS E M, LARRAIN J, OELGESCHLÁGER M, WESSELY O (2000). The establishment of Spemann's organizer and patterning of the vertebrate embryo. Nat Rev Genet 1: 171-181.

FANG H, MARIKAWAY, ELINSON RP (2000). Ectopic expression of Xenopus noggin RNA induces complete secondary axes in embryos of the direct developing frog Eleutherodactylus coqui. Dev Genes Evol 10: 21-27.

GALLIOT B, SCHMID V (2002) Cnidarians as a model system for understanding evolution and regeneration. Int J Dev Biol 46: 39-48.

GERHART J (1999). 1998 Warkany lecture: Signaling pathways in development. Teratology 60: 226-239.
GHASKADBI S (1996). Mesoderm induction in amphibians and chick. J Biosci 21 353-368.

GHASKADBI S and MULHERKAR L (1984). Cellular disaggregation and enucleation in Hydra due to treatment with cytochalasin $\mathrm{H}$. In Proceedings of the Fifth All India Symposium on Developmental Biology (Eds S.K. Agarwal and S.C. Goel). Indian Society of Developmental Biologists, Pune, pp. 87-91.

GILBERT SF and BARRESI M J (2018). Developmental Biology, International Eleventh Edition, Oxford University Press, New York.

GROPPE J, GREENWALD J, WIATER E, RODRIGUEZ-LEON J, ECONOMIDES A N, KWIATKOWSKI W, AFFOLTER M, VALE W W, IZPISUA BELMONTE J C, CHOE S (2002). Structural basis of BMP signalling inhibition by the cysteine knot protein noggin. Nature 420: 636-642.

HAWLEY S H, WÜNNERBERG-STAPLETON K, HASHIMOTO C, WATABE T, BLUMBERG B W, CHO K W (1995). Disruption of BMP signals in embryonic Xenopus ectoderm leads to direct neural induction. Genes Dev 9: 2923-2935.

HEMMATI-BRIVANLOUA, KELLYO G, MELTONDA(1994). Follistatin, an antagonist of activin, is expressed in the Spemann organizer and displays direct neutralizing activity. Cell 77: 283-295.

HOBMAYER B, RENTZSCH F, HOLSTEIN T W (2001). Identification and expression of HySmad1, a member of the R-Smad family of TGFb signal transducers, in the diploblastic metazoan hydra. Dev Genes Evol 211: 597-602.

HOBMAYER B, RENTZSCH F, KUHN K, HAPPEL C M, VON LAUE C C, SNYDER P, ROTHBÄCHER U, HOLSTEIN T W (2000). WNT signaling molecules act in axis formation in the diploblastic metazoan hydra. Nature 407: 186-189.

HOBMAYER E, HATTA M, FISCHER R, FUJISAWA T, HOLSTEIN T W, SUGIYAMA, T (1996). Identification of a hydra homologue of the beta-catenin/plakoglobin/ armadillo gene family. Gene 172: 155-159.

JIN K, ZHUY, SUNY, MAO XO, XIE L, GREENBERG DA (2002). Vascular endothelial growth factor (VEGF) stimulates neurogenesis in vitro and in vivo. Proc Natl Acad SCi USA 99: 11946-11950.

KADU V, GHASKADBI S S, GHASKADBI S (2012). Induction of secondary axis in hydra revisited: New insights into pattern formation. Int $J$ Mol Cell Med 1: 11-20.

KÄSBAUERT, TOWB P, ALEXANDROVAO, DAVID C N, DALL'ARMI E, STAUDIGLA, STIENING B, BÖTTGER A (2007). The notch signaling pathway in the cnidarian hydra. Dev Biol 303: 376-390.

KHOKHA M K, YEH J, GRAMMER T C, HARLAND R M (2005). Depletion of three BMP antagonists from Spemann's organizer leads to a catastrophic loss of dorsal structures. Dev Cell 8: 401-411.

KRISHNAPATI L S, GHASKADBI S (2013). Identification and characterization of VEGF and FGF from hydra. Int $J$ Dev Biol 57: 897-906.

LAMB T M, KNECHT A K, SMITH W C, ECONOMIDES A N, STAHL N, YANCOPOLOUS G D, HARLAND R M (1993). Neural induction by the secreted polypeptide noggin. Science 262: 713-718.

LANGE E, BERTRAND S, HOLZ O, REBSCHER N, HASSEL M (2014). Dynamic expression of a hydra FGF at boundaries and termini. Dev Genes Evol224:235-244.

MARTINEZ D E (1998). Mortality patterns suggest lack of senescence in hydra. Exp. Gerontol 33: 217-225.

MARTINEZ D E, BRIDGE D (2012) Hydra, the everlasting embryo. Int J Dev Biol 56: $479-487$

MARTINEZ D E, IÑIGUEZ A R, PERCELL K M, WILLNER J B, SIGNOROVITCH J, CAMPBELLRD (2010) Phylogeny and biogeography of Hydra (Cnidaria: Hydridae) using mitochondrial and nuclear DNA sequences. Mol Phylogen Evol 57:403-410.

MATUS DQ, THOMSEN GH, MARTINDALE MQ (2007). FGF signaling in gastrulation and neural development in Nematostella vectensis, an anthozoan cnidarian. Dev Genes Evol 217: 137-148.

MEINHARDT H (2002). The radial-symmetric hydra and the evolution of the bilateral body plan: an old body became a young brain. BioEssays 24: 1850191.

MEINHARDT H (2004). Different strategies for midline formation in bilaterians. Nat Rev Neurosci 5: 502-510.

MILLER M A, STEELE R E (2000) Lemon encodes an unusual receptor proteintyrosine kinase expressed during gametogenesis in hydra. Dev Bio/224: 286-298.

MÜLLER G B (2007). Evo-devo: Extending the evolutionary synthesis. Nature Rev Genet 8: 943-949.

MÜLLERWA(1996). Pattern formation in the immortal hydra. Trends Genet 12:91-96. 
MÜNDER S, KÄSBAUER T, PREXL A, AUFSCHNAITER R, ZHANG X, TOWB P, BÖTTGER A (2010). Notch signaling defines critical boundary during budding in hydra. Dev Biol 344: 331-345.

MÜNDER S, TISCHER S, GRUNDHUBER M, BÜCHELS N, BRUCKMEIER N, ECKERT S, SEEFELDT C A, PREXL A, KÄSBAUER T, BÖTTGER A (2010). Notch-signaling is required for head regeneration and tentacle patterning in hydra. Dev Biol 383: 146-157.

NIEUWKOOP P D (1952). Activation and organization of the central nervous system in amphibians. Part III. Synthesis of a new working hypothesis. J. Exp. Zool. 120: 83-108.

NIEUWKOOP P D (1985). Inductive interactions in early amphibian development and their general nature. J Embryol Exp Morphol 89 (Suppl): 333-347.

PHILIPPI, AUFSCHNAITERR, OZBEKS, PONTASCHS, JENEWEIN M, WATANABE H, RENTZSCH F, HOLSTEIN T W, HOBMAYER B (2009) Wnt/beta-catenin and noncanonical Wnt signaling interact in tissue evagination in the simple eumetazoan hydra. Proc Natl Acad Sci USA 106: 4290-4295.

REDDY P C, BIDAYE S S, GHASKADBI S (2011) Genome-wide screening reveals the emergence and divergence of RTK homologues in basal metazoan Hydra magnipapillata. J Biosci 36: 289-296.

REINHARDT B, BROUN M, BLITZ I L, BODE H (2004). HyBMP5-8b, a BMP5-8 orthologue, acts during axial patterning and tentacle formation in hydra. Dev Biol 267: 43-59.

RENTZSCH F, GUDER C, VOCKE D, HOBMAYER B, HOLSTEIN T W (2007). An ancient Chordin-like gene in organizer formation of hydra. Proc Natl Acad Sci USA 104: 3249-3254.

RUIZ DE ALMODOVAR C, LAMBRECHTS D, MAZZONE M, CARMELIET P (2009). Role and therapeutic potential of VEGF in the nervous system. Physiol Rev 89: 607-648.

SASAI Y, LU B, STEINBEISSER H, DE ROBERTIS E M (1995). Regulation of neural induction by the Chd and BMP-4 antagonistic patterning signals in Xenopus.
Nature 376: 333-336.

SASAI Y, LU B, STEINBEISSER H, GEISSERT D, GONT L K, DE ROBERTIS E M (1994). Xenopuschordin: a novel dorsalizing factor activated by organizer-specific homeobox genes. Cell 79: 779-790.

SMITH J C (1989). Mesoderm induction and mesoderm-inducing factors in early amphibian development. Development 105: 665-677.

SMITH W C, HARLAND R M (1992) Expression cloning of noggin, a new dorsalizing factor localized to the Spemann organizer in Xenopus embryo. Cell 70: 829-840.

SMITH W C, KNECHT A K, WU M, HARLAND R M (1993). Secreted noggin protein mimics the Spemann organizer in dorsalizing Xenopus mesoderm. Nature 361 547-549.

STEELE R E, LIEU P, MAI N H, SHENK M A, SARRAS M P JR (1996). Response to insulin and the expression pattern of a gene encoding an insulin receptor homologue suggest a role for an insulin-like molecule in regulating growth and patterning in hydra. Dev Genes Evol 206: 247-259.

SUDHOPS, COULIER F, BIELLERA, VOGTA, HOTZT, HASSELM (2004). Signalling by the FGFR-like tyrosine kinase, Kringelchen, is essential for bud detachment in Hydra vulgaris. Development 131: 4001-4011.

SUGIYAMA T, FUJISAWA T (1978) Genetic analysis of developmental mechanism in hydra. II. Isolation and characterization of an interstitial cell-deficient strain. $J$ Cell Sci 29: 35-52.

TISCHER S, REINECK M, SÖDING J, MÜNDER S, BÖTTGER A (2013). Eph receptors and ephrin class B ligands are expressed at tissue boundaries in Hydra vulgaris. Int J Dev Biol 57: 759-765.

VAN DER GEER P, HUNTER T, LINDBERG R A (1994). Receptor protein-tyrosine kinases and their signal transduction pathways. Annu Rev Cell Biol 10: 251-337.

WATANABE H, SCHMIDT H A, KUHN A, HÖGER S K, KOCAGÖZ Y, LAUMANNLIPP N, OZBEK S, HOLSTEIN T W (2014). Nodal signaling determines bilateral asymmetry in hydra. Nature 515: 112-115. 


\section{Further Related Reading, published previously in the Int. J. Dev. Biol.}

Real time dynamics of $\beta$-catenin expression during Hydra development, regeneration and Wnt signalling activation Roberta lachetta, Alfredo Ambrosone, Alexander Klimovich, Jörg Wittlieb, Giada Onorato, Alessia Candeo, Cosimo D'Andrea, Daniela Intartaglia, Nunzia Scotti, Martina Blasio, Angela Tino, Andrea Bassi and Claudia Tortiglione

Int. J. Dev. Biol. (2018) 62: 311-318

https://doi.org/10.1387/ijdb.180092ct

UV induced foot duplication in regenerating hydra is mediated by metalloproteinases and modulation of the Wnt pathway Lakshmi-Surekha Krishnapati, Rohini Londhe, Vaishali Deoli, Apurva Barve, Saroj Ghaskadbi and Surendra Ghaskadbi

Int. J. Dev. Biol. (2016) 60: 111-117

https://doi.org/10.1387/ijdb.130253sg

\section{Identification and characterization of VEGF and FGF from Hydra}

Lakshmi-Surekha Krishnapati and Surendra Ghaskadbi

Int. J. Dev. Biol. (2013) 57: 897-906

https://doi.org/10.1387/ijdb.130077sg

Eph receptors and ephrin class B ligands are expressed at tissue boundaries in Hydra vulgaris

Susanne Tischer, Mona Reineck, Johannes Söding, Sandra Münder and Angelika Böttger Int. J. Dev. Biol. (2013) 57: 759-765

https://doi.org/10.1387/ijdb.130158ab

Hydra, a fruitful model system for $\mathbf{2 7 0}$ years

Brigitte Galliot

Int. J. Dev. Biol. (2012) 56: 411-423

https://doi.org/10.1387/ijdb.120086bg

Hydractinia, a pioneering model for stem cell biology and reprogramming somatic cells to pluripotency

Günter Plickert, Uri Frank and Werner A. Müller

Int. J. Dev. Biol. (2012) 56: 519-534

https://doi.org/10.1387/ijdb.123502gp

\section{Peptide signaling in Hydra}

Toshitaka Fujisawa and Eisuke Hayakawa

Int. J. Dev. Biol. (2012) 56: 543-550

https://doi.org/10.1387/ijdb.113477tf

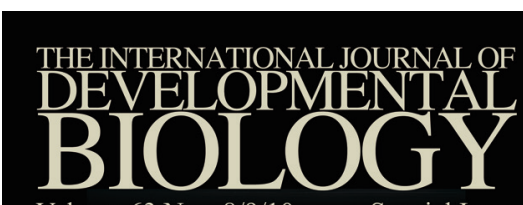

Volume 63 Nos. 8/9/10
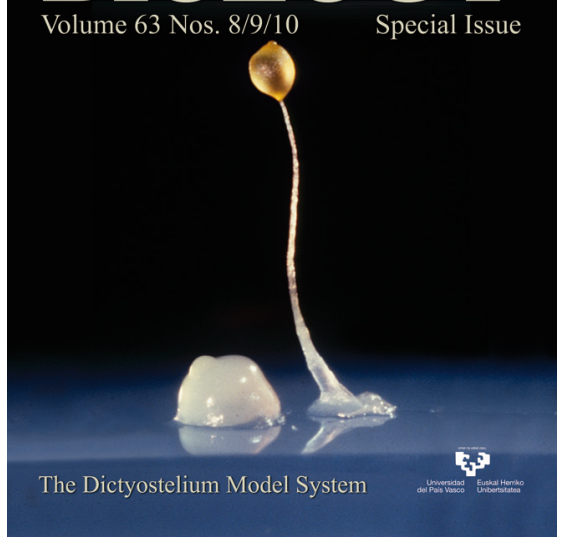

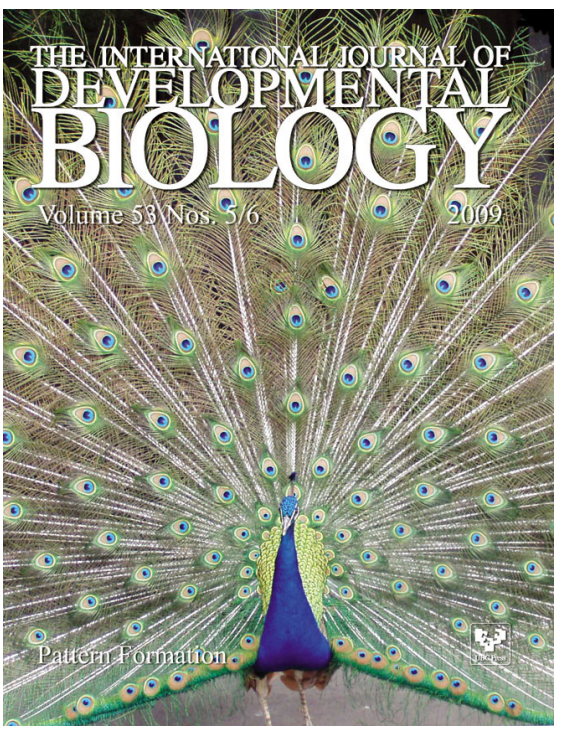

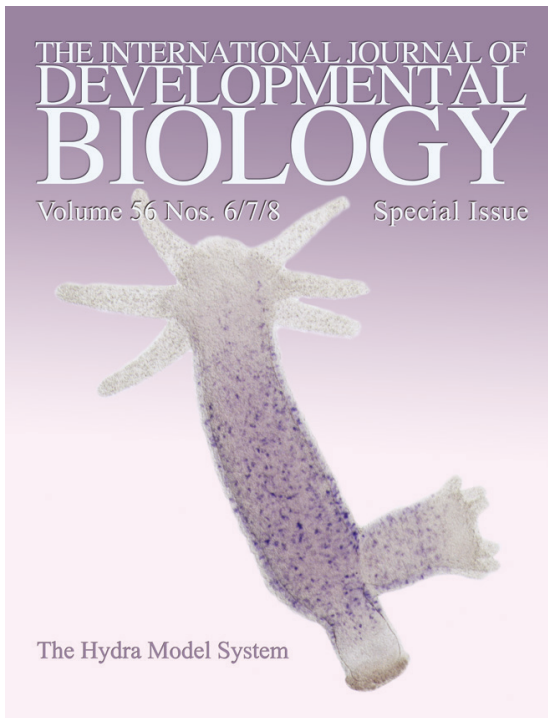

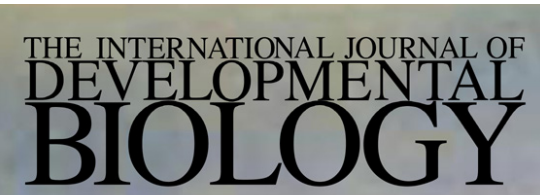

Volume 47 Nos. $7 / 8$ Special Issue

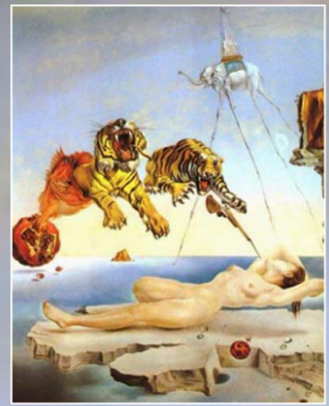

Evolution \& Development 